\title{
ОСОБЛИВОСТІ ГРУПОВОЇ ПСИХОЛОГІЧНОЇ РОБОТИ З ДІТЬМИ, ЯКІ ОТРИМАЛИ ТРАВМАТИЧНИЙ ДОСВІД
}

\section{Бондарук Юлія}

Український науково-методичний центр практичної психології і соціальної роботи, м. Київ, Україна, yulenkaserg@gmail.com, http://orcid.org/0000-0001-9162-1811

Mema. У статті розглянуто питання надання психологічної допомоги травмованим дітям, які постраждали внаслідок військового конфлікту та опинились у складних життєвих обставинах. Мета статті полягає в тому, щоб охарактеризувати основні чинники, які впливають на ефективність групової психологічної роботи з травмованими дітьми в умовах закладу освіти.

Методами дослідження $\epsilon$ аналіз та узагальнення теоретичних джерел вітчизняних i зарубіжних учених із питань надання психологічної допомоги постраждалим дітям, які отримали травматичний досвід.

Результати аналізу теоретичних джерел дають підставу виділити й охарактеризувати основні психологічні підходи в роботі з психотравмою саме в дітей, що найчастіше представлені в межах ігрового підходу в різних його модифікаціях: клієнт-центрованої орієнтації, структурної ігрової терапії або інших видах. Аналіз досліджень дає підставу стверджувати, що основними цілями під час надання допомоги дітям $\epsilon$ відреагування травматичних переживань, стабілізація емоційного стану та відновлення соціальної взаємодії між дітьми й основними методами роботи психолога $є$ ті, що грунтуються на ігровій терапії, центрованій на дитині. У випадку, коли дитина переживає певну подію не одноразово, а опиняється в нових (або складних) життєвих обставинах, завданням психологічної допомоги буде не відреагування емоцій, а адаптація. I в цьому випадку більш ефективним є підхід, що грунтується на теорії соціального научіння.

Висновки. Основними чинниками, що впливають на ефективність групової роботи 3 дітьми, є побудова та організація ігрової роботи відповідно до визначення етапів переживання психотравми, підбір і володіння відповідними методами й методиками роботи з урахуванням вікових та індивідуальних особливостей дітей, а також урахування динаміки групової роботи й успішне керівництво ведучого груповими процесами. До таких чинників потрібно віднести досвід роботи $з$ травматичними переживаннями в дітей, професіоналізм та особистісні якості ведучого групи.

Ключові слова: психологічна травма, груповий процес, ігрова терапія, взаємодія, діти, методи, відреагування. 
Bondaruk Yuliia. Features of Group Psychological Work with Children Who Have Received Traumatic Experience. Purpose. The article considers the issues of providing psychological assistance to traumatized children who suffered as a result of the military conflict and found themselves in difficult life circumstances. The purpose of the article is to characterize the main factors that affect the effectiveness of group psychological work with injured children in an educational institution.

The Research Methods are the analysis and generalization of theoretical sources of domestic and foreign scientists on the provision of psychological assistance to affected children who have received traumatic experiences.

The Results of the analysis of theoretical sources allow identifying and characterizing the main psychological approaches in dealing with trauma in children, which are most often presented within the game approach in its various modifications: client-centered orientation, structural game therapy or other types.

Analysis of research suggests that the main goals in helping children are to respond to traumatic experiences, stabilize emotional state and restore social interaction between children and the main methods of work of a psychologist are those based on child-centered play therapy. In the case when a child experiences a certain event not once, but finds himself in new (or difficult) life circumstances, the task of psychological help will not be emotional response, but adaptation, and in this case a more effective approach based on social learning theory.

Conclusions. The main factors influencing the effectiveness of group work with children are the construction and organization of play in accordance with the stages of psychotrauma, selection and possession of appropriate methods and techniques taking into account the age and individual characteristics of children, as well as group processes. To these factors should be added the experience of working with traumatic experiences in children, professionalism and personal qualities of the group leader.

Key words: psychological trauma, group process, game therapy, interaction, children, methods, response

Бондарук Юлия. Особенности групповой психологической работы с детьми, которые получили травматический опыт. Цель. В статье рассматриваются вопросы оказания психологической помощи травмированным детям, пострадавшим в результате военного конфликта, и тем, что оказались в сложных жизненных обстоятельствах. Цель статьи - охарактеризовать основные факторы, влияющие на эффективность групповой психологической работы с травмированными детьми в условиях образовательного учреждения.

Методами исследования является анализ и обобщение теоретических источников отечественных и зарубежных ученых по вопросам оказания психологической помощи пострадавшим детям, получившим травматический опыт.

Результаты анализа теоретических источников позволяют выделить и охарактеризовать основные психологические подходы в работе с психотравмой именно у детей, чаще всего они представлены в пределах игрового подхода в различных его модификациях: клиент-центрированной ориентации, структурной 
игровой терапии или других видах. Анализ исследований позволяет утверждать, что основными целями при оказании помощи детям являются отреагирование травматических переживаний, стабилизация эмоционального состояния и восстановление социального взаимодействия между детьми и основными методами работы психолога являются те, которые основываются на игровой терапии, центрированной на ребенке. В случае, когда ребенок переживает определенное событие не единовременно, а оказывается в новых (или сложных) жизненных обстоятельствах, задачей психологической помощи будет не отреагирование эмоций, а адаптация и в этом случае более эффективным является подход, основанный на теории социального научения.

Bblвodbl. Основными факторами, влияющие на эффективность групповой работы с детьми, являются построение и организация игровой работы в соответствии с определением этапов переживания психотравмы, подбор и владение соответствующими методами и методиками работы с учетом возрастных и индивидуальных особенностей детей, а также учета динамики групповой работы и успешное руководство ведущего групповыми процессами. К перечисленным факторам следует добавить опыт работы с травматическими переживаниями у детей, профессионализм и личностные качества ведущего группы.

Ключевые слова: психологическая травма, групповой процесс, игровая терапия, взаимодействие, дети, методы, отреагирование.

Вступ. Військовий конфлікт на Сході України триває й досі та $є$ психотравмувальними чинником як для дорослих, так i для дітей. Передусім, найбільше постраждали діти, котрі перебували в зоні бойових дій, а також діти, які втратили батьків або інших родичів та близьких людей.

Потрібно також додати, що існує багато інших джерел травмування, таких як стихійні лиха чи природні катастрофи, стресові події, терористичні акти, насилля, нещасні випадки, важкі або невиліковні хвороби, аварії, різні втрати та ін. Травматичні події часто набувають великого масштабу й зачіпають не лише окрему людину, але й цілі народи та країни.

Потужні стресові переживання, пов'язані з утратою звичного способу життя, страхом смерті, утратою рідного дому, почуття безпеки та економічною й соціальною невизначеністю негативно впливають на психічний стан дітей і їхніх батьків. Травмувальні події призводять до втрати дитиною стабільного, безпечного та підтримувального оточення, яке $\epsilon$ важливою умовою для гармонійного розвитку психіки дітей. Через економічні проблеми або важкий стрес батькам бракує власних сил і вони не завжди можуть приділяти достатньо уваги вихованню дітей, виконувати звичні сімейні ролі та 
обов'язки, сприяти задоволенню потреб або розв'язанню конкретних проблем, котрі виникають у дитини.

А тому вищезазначена ситуація й зумовлена нею проблематика вимагають пошуку та застосування ефективних і дієвих методів психологічної допомоги постраждалим дітям та сім'ям. Вивчаючи різні аспекти роботи практичного психолога закладу освіти, можемо зазначити, що значне місце в його роботі займає психологічне консультування дітей і батьків, а також педагогічних працівників. У випадку роботи психолога з травмованими дітьми та сім'ями спочатку, зазвичай, відбувається певна індивідуальна робота, що включає різні діагностичні процедури, а також певні консультативні чи психокорекційні заходи. А вже після цього здійснюється групова форма роботи.

Аналіз останніх досліджень і публікацій. Вивчення наукової літератури та практичного досвіду фахівців свідчить, що надання психологічної допомоги постраждалим дітям i їхнім батькам $\epsilon$ відносно новим видом професійної діяльності. Тому такі вітчизняні дослідники, як В. Г. Панок, І. І. Ткачук, Н. В. Лунченко, наголошують на тому, що завдання психологічної реабілітації дітей і сімей, які пережили важку психічну травму, принципово різні одразу після неї й через певний час (кілька місяців, років). На першому етапі психологічна допомога може бути охарактеризована як медико-психологічна, на другому - як психолого-педагогічна. Це визначає і вибір фахівців, які виконують таку роботу. Важливо, що ця робота має бути системною, тривалою й проводитися на високому науково-методичному рівні (Панок та ін., 2019).

На думку дослідників Е. Дирегров, У. Юле, чим швидше допомогти дитині впоратися зі стресом, тим краще вона почуватиметься й тим менший ризик виникнення проблем у майбутньому. У випадку значної кількості постраждалих першим завданням є якнайшвидше надання допомоги одразу великій чисельності дітей (Dyregrov, 2008; Yule 1994).

Мета статті - охарактеризувати основні чинники, які впливають на ефективність групової психологічної роботи з травмованими дітьми в умовах закладу освіти.

Методи дослідження. У статті використано такі методи дослідження, як аналіз та узагальнення теоретичних джерел вітчизняних i зарубіжних учених із питань надання психологічної допомоги постраждалим дітям, які отримали травматичний досвід. 
Виклад основного матеріалу. Потрібно зауважити, що психологічні проблеми дітей та сімей, що постраждали внаслідок військового конфлікту на Сході України, мають комплексний характер. Загальною причиною і ядром цих проблем $\epsilon$ важкий травматичний досвід, переживання якого ускладнюється необхідністю адаптуватись у новому середовищі. Це часто супроводжується ретравматизацією, коли одна травма накладається на іншу, тобто первинною травмою $є$ загроза життю, безпеці й благополуччю, а вторинною - необхідність адаптуватися, пристосовуватися до нових умов чи нового (незнайомого) середовища (Удовенко, 2017). Однією з найуразливіших категорій населення, котре постраждало внаслідок військового конфлікту, $\epsilon$ діти та підлітки, оскільки їхній психічний розвиток перебуває в процесі формування й вони $є$ недостатньо зрілими для переживання психотравмувальних ситуацій, а також мають слаборозвинені механізми адаптації та компенсації. Ці й інші психотравмувальні чинники негативно впливають на дітей саме в період розвитку, порушуючи процеси формування та становлення особистості. Шкільні психологи зауважують, що важкий травматичний досвід впливає не лише на особливості поведінки, а й на когнітивні процеси, самооцінку, міжособистісні стосунки, світогляд у цілому. А тому одним із важливих завдань у роботі з цією категорією дітей є створення таких умов, що сприяють їхньому особистісному зростанню та розвитку, а також позбавленню від того, що перешкоджає цим процесам. У шкільній психологічній практиці такі можливості надає саме групова робота, коли сама група виступає основною умовою розвитку особистості дитини та розв'язання проблем (Мушкевич та ін., 2016).

Групова форма психологічного консультування має низку особливостей, що чинять як корекційний, так і терапевтичний вплив:

- група виступає як мінімодель соціуму, оскільки в групі створюється ситуація, за якою людина проявляє таке саме ставлення, установки, цінності, ті самі способи емоційного реагування й поведінкові реакції, що й у реальному житті; також група надає зворотний зв'язок щодо поведінки людини та, грунтуючись на ньому, вона може усвідомлювати власні поведінкові установки й, за необхідності, змінювати їх на більш продуктивні (наприклад через експерименти з альтернативними способами поведінки); 
- групова динаміка, що характеризується соціально-психологічними процесами та явищами, що відбуваються в групі протягом іiі розвитку й зміни, здійснює вплив на всіх учасників групи;

- аналіз рольових стереотипів може допомогти усвідомити та скоректувати непродуктивні способи взаємодії й адаптації в середовищі;

- консультативні групи, зазвичай надають своїм учасникам розуміння й підтримку, що, зі свого боку, підсилює готовність учасників досліджувати та розв'язувати проблеми, із якими вони прийшли до групи (Горностай, 2013).

У сучасній психологічній практиці існує дуже багато видів консультативних груп, найбільш популярними з них є тренінгові або психокорекційні групи. Дж. Корі, вивчаючи різні види консультативних груп, виокремив основні стадії розвитку групи, а також деякі важливі аспекти, що виникають у процесі роботи 3 групою. Наприклад, консультант може стикатись із так званими «важкими» членами групи, дії яких потрібно розглядати як частину групового процесу. А тому, аби такі учасники не ускладнювали продуктивну роботу 3 іншими, буде корисним звернути на них увагу групи, показати їм, як вони виглядають в очах інших, а також звернути увагу інших учасників на їхні власні реакції на тих членів групи, які чинять супротив. Дж. Корі також рекомендує консультантові активно працювати 3 власною реакцією на психологічний опір членів групи, оскільки при його ігноруванні консультант ризикує бути «вимкненим» із взаємодії з групою (Корі, 2003).

В основу найбільш відомого опису групового процесу покладено теорію міжособистісних взаємин, згідно з якою на ранніх стадіях існування групи в поведінці учасників переважає потреба у включеності до групи, тобто почутті належності до неї й у досягненні задовільних відносин у ній. Пізніше виникає потреба в контролі. На цій стадії виникають суперництво та прагнення влади й учасники груп вступають у боротьбу за лідерство та домінування. Нарешті на стадії зрілості групи, коли іï учасники встановлюють тісний емоційний взаємозв'язок одне з одним, особливого значення набувають близькість, партнерство та взаємне тяжіння. На цьому етапі переважає потреба в прив'язаності (Горностай, 2013). Потрібно підкреслити, що в слабоорганізованих групах із малозрозумілими цілями та правилами поведінки може виникати неприязнь між учасниками й стрес через 
суперечки. Отже, це треба враховувати під час організації та проведення роботи $з$ дітьми й підлітками.

Також потрібно додати, що так само, як і за індивідуального консультування, у груповій роботі психолог часто використовує ті самі техніки, а саме: активне слухання, перефразування, роз'яснення, підбиття підсумків. Особливо в кінці групової зустрічі: запитання, інтерпретація, конфронтація, відображення почуттів, підтримка, емпатія, фасилітація, ініціативність, постановка цілей, оцінка та рефлексія, зворотний зв’язок, порада, пропозиція, захист, саморозкриття, моделювання, зв'язок, блокування та ін.

Серед різних психологічних підходів у роботі з дитячою травматикою значне місце посідає ігрова терапія. Особливо, якщо йдеться про дітей молодшого шкільного віку, для яких у цей віковий період гра та навчання є провідною діяльністю. До того ж дитина в такому віці ще не має запиту чи потреби в психологічній консультації й частіше за все не звертається по допомогу до психолога (Бондарук, 2019). У цьому віці активно розвиваються емоційно-вольова сфера, яка включає навички самоконтролю, стресостійкості. Тому важливо розвивати вміння відслідковувати та усвідомлювати власні думки й почуття, уміти розрізняти та називати власні почуття. Такі здібності відіграють важливу роль у розвитку емпатії, налагодженні стосунків 3 оточенням, прояву комунікабельності та довіри до світу. Під час застосування ігор або ігрових вправ у дитини відбувається відреагування емоційних станів, розвиток усвідомленості й виваженості в прийнятті рішень, здійснення суджень та аналізу певних соціальних ситуацій, а також підвищення когнітивних здібностей для покращення шкільної успішності.

Можливості психологічної гри дуже широкі, оскільки вона (якщо ретельно іiі підготувати й продумати) цілком захоплює дитину. Це єдність думок, почуттів та рухів, це гармонійне життя в образі, ролі, ситуації, світі. Гра - це унікальний фантастичний простір із великим творчим потенціалом. Можна творити себе, свої відносини з іншими, власне майбутнє в абсолютно безпечній атмосфері та ситуації. Граючи певну роль, можна дозволити собі бути самим собою. Хороша гра - це ніби психологічний експеримент, який здійснює кожний учасник i результати якого не завжди передбачувані, а зазвичай - часто неочікувані, а іноді й болісні. Тому, якщо в учасника немає сил прийняти та усвідомити новий досвід, гра надає йому безпечний вихід, захист у 
розумінні того, що то була роль у грі, а в житті все по-іншому. Це дуже важливо в будь-якому віці, а особливо в дитячому й підлітковому.

Потрібно зазначити, що для певної категорії дітей бажання грати зумовлене потребою в сильних і цілісних емоційних переживаннях, особливо для молодших школярів. Гра для них надає можливість емоційно відреагувати на різні хвилювання та труднощі, побудувати на рівні почуттів відносини 3 навколишніми й навчитися контролювати та регулювати свій внутрішній світ. У підлітків гра є безпечним простором побудови відносин з оточенням. Дівчата - хлопці, лідери послідовники, «зірки» - ізольовані - усе це системи відносин, які підліткам дуже важко усвідомлювати, будувати й змінювати в реальному житті. А в грі їм надається така можливість. Особливо потреба в грі виникає тоді, коли не хочеться розмов. Але вдале обговорення після гри свідчить про зміни у відносинах, внутрішне зростання учасників. Для старших школярів характерне сприйняття гри як психологічної можливості зрозуміти себе й інших, побачити та відчути перспективи розвитку, прожити моделі поведінки, відносин, що до цього здавалися неможливими або були недоступні. У цьому випадку гра виступає як лабораторія, інструмент пізнання та розвитку. Зазвичай, у таких групах відбуваються бурхливі й тривалі обговорення, а опір до нових ігрових форм - мінімальний. У цих варіантах ставлення до гри відображаються етапи особистісного розвитку. Тому систематична робота з розвитку «ігрового потенціалу» школярів має велике значення та розглядається як один із важливіших напрямів діяльності шкільного психолога (Бітянова, 2005: 9).

Вивчаючи групову терапевтичну роботу 3 дітьми, Р. Смід виокремила джерела проблем, які виникають у дитячих групах. Так, у дітей молодшого шкільного віку - це найчастіше прояви агресії, монополізація, привертання уваги, опір або недовіра. У підлітків частіше трапляються випадки порушення конфіденційності, утворення угруповань, бійки. І незалежно від віку - усі діти плачуть. Проте Смід закликала кожну таку проблемну ситуацію розглядати як точку зростання групи, адже вони надають можливість дізнатися нове про взаємини й про те, що можна зробити для їх покращення. I завданням ведучого буде використати ऑї як джерело нового та цікавого досвіду (Смід, 2000). Потрібно зауважити, що травмовані діти можуть пропускати групові заняття й це не обов'язково через небажання брати участь у них. На думку Богданова С., це може свідчити про ступінь 
переживання стресу дитиною, важкі переживання і іï страх говорити про себе в групі. А тому це може бути сигналом для додаткових індивідуальних консультацій, після завершення яких можливе й навіть бажане повернення до групової форми роботи та спілкування з іншими учасниками (Богданов, 2016).

Аналізуючи психологічні підходи в роботі 3 психотравмою, зазначимо, що значну популярність набуває підхід, котрий грунтується на клієнт-центрованій терапії на дитині Г. Л. Лендрета. I особливо він виявив себе ефективним під час роботи 3 травмованими дітьми, оскільки дає змогу дитині в ігровій діяльності програвати в символічній формі ті травматичні обставини чи події, які відбулися в іiі житті. Змістом циклічної гри можуть бути похорон, розлучення батьків або інший сюжет, який є для дитини травматичною подією, під час якої психолог описує дії дитини, повторює іiі слова, мовлення й називає іiі почуття, що дає змогу дитині відреагувати накопичені емоції гніву, смутку, страху тощо. Коментуючи зміст циклічної гри, психолог не дає жодних указівок і не виконує при цьому жодних навчальновиховних дій, а тому дитина розуміє, що вона може вільно виражати власні емоції в присутності психолога. У результаті відбувається поєднання в психіці дитини іiі слів (мовлення), iї почуттів, iї дій. Те, що розщеплено в результаті отриманого травматичного досвіду. Коли циклічна гра завершується, дитина в змозі демонструвати, показувати останні події, що відбувалися в ііі реальності або уяві. Іїі загальний стан покращується, симптоми, на які скаржилися батьки, теж зникають самі без спеціальної корекції (Лендрет, 2007).

Розвиваючи ідею ігрового підходу, Д. Леві запропонував ідею структурованої ігрової терапії для роботи з дітьми, які пережили певні травматичні події. У своїй роботі він відтворював таку обстановку, щоб спеціально відібрані іграшки допомогли дитині відтворити той досвід, який викликав у дитини реакцію тривоги. У процесі розігрування попереднього досвіду дитина керує грою й тим самим переміщується з пасивної ролі постраждалого в активну роль того, хто діє. Слідкуючи за грою, ігротерапевт позначає словами, промовляє вголос, відображує вербальні та невербальні почуття дитини (Лендрет, 2007).

Високоефективною в роботі з травмованими дітьми себе зарекомендувала й методика Вайолет Оклендер, основні положення якої викладено в іiі роботі «Вікна у світ дитини». I тут особливість процесу відреагування полягає в тому, що психолог не просто присутній під 
час вираження емоцій дитини, але й активно стимулює їх через малювання, танці, ліплення тощо. (Oaklander, 1988).

Більшу структуру в процес ігрової терапії вніс А. I. Захаров, який розробляв і застосовував групову роботу з дітьми та підлітками, а також вивчав можливості поєднання сімейної й групової терапії. Він запропонував таку послідовність корекційних методик: 1) бесіда; 2) спонтанна гра; 3) спрямована гра; 4) навіювання. В організації терапевтичного процесу Захаров виділяє діагностичну, терапевтичну та навчальну функції гри. Як спонтанна гра, так і спрямована звичайно нагадує імпровізацію будь-якого сюжету. У процесі роботи можна виокремити такі етапи: об'єднання дітей у групу, розповіді, ігри та обговорення. Так, об'єднання дітей починається зі спільної та цікавої для всіх діяльності. Розповіді, зазвичай, складаються вдома та по черзі розповідаються в групі. Гра проводиться на тему, котру запропонують діти та психолог. В іграх послідовно відтворюються розповіді, казки, умовні та реальні ситуації. Із часом роботи групи змінюється зміст рольових ігор від терапевтично спрямованих до навчальних. Метою терапевтичних ігор є усунення перешкод у міжособистісних відносинах, а навчальних - більш адекватної адаптації та соціалізації дітей. Рольова гра являє собою акт творчості й саморозкриття, що дає можливість краще зрозуміти себе та інших і перебудувати свої відносини. Для цього вона будується на основі імпровізації як індивідуальної форми самовираження, різноманітності й зміни сюжетів, їх захопливості та актуальності для дітей. Важливо, щоб теми ігор змінювались, аби уникнути рутинності й штампів, а тривалість не перевищувала 45 хвилин часу, щоб не призводити до перенасиченості та втрати інтересу до гри. Завершальним етапом роботи буде обговорення (Захаров, 2006).

У випадку, коли дитина переживає певну подію не одноразово, а опиняється в нових (або складних) життєвих обставинах, доречно застосовувати підхід, що грунтується на теорії соціального научіння. Якщо в житті дитини щось не просто відбулось, а продовжується й триває в часі, завданням психологічної допомоги буде не відреагування емоцій, а адаптація. I тому в процесі ігрової роботи психолог може, наприклад, складаючи історії (вигадуючи по черзі з дитиною по одному реченню) або малюючи спільні малюнки, демонструвати різні копінг-стратегії, із якими дитина може погоджуватись або не приймати. Використовуючи модифікацію сюжету відомої казки чи 
мультфільму, можемо вигадувати власну історію в спільній творчості психолога й дитини. Отже, в ігровому процесі, психолог разом із дитиною знаходять різні варіанти опанування травмувальної ситуації, аби дитина могла обрати той, що їй підходить і який вона зможе використовувати надалі. У дитячих групах діти можуть по черзі вигадувати по одному реченню, наприклад, придумуючи страшну історію чи казку. Важливо, що діти можуть говорити про свої страхи відверто, залишаючись при цьому в безпеці, адже історія не про них (Тарасова, 2017:517).

Німецький учений Готфрід Фішер, який запропонував інтегративний підхід у роботі з психотравмами, наголошує, що в людини відбуваються зміни в сприйнятті, що спотворюють відчуття часу, простору й самого себе. Швидкоплинний або, навпаки, сповільнений час, споглядання за тим, що відбувається, ніби збоку, свідчать про ознаки дисоціативного (розщепленого) сприйняття. Тобто постраждалі, не маючи можливості «втекти», уникають шляхом зміни в рецепторній сфері або в сприйнятті. Тому, аби симптоми травматичної реакції не ставали хронічними, головною метою в подальшій роботі $\epsilon$ доопрацювання змісту переживань й інтеграція травматичного досвіду у свідомість людини. Важливим моментом переробки травматичного досвіду є контрольоване повернення у важку ситуацію, спогади про неї та прояв почуттів, пов'язаних із нею. Відносне завершення ситуації можливе лише в тому випадку, якщо постраждалі інтегрують та приймуть пережитий досвід як складову частину свого життя. Успішним завершенням роботи можна вважати здатність постраждалого згадувати травматичну ситуацію без занурення в афективність і нав'язливі думки про минуле (Фішер, 2003).

Е. Дирегров, У. Юле наголошують на тому, що психологу, який працює з травмованими дітьми, важливо підбирати для роботи в групі ті методики, які надають можливість дітям і підліткам відчути та побачити зв'язок між думками й емоціями. А саме навчити дітей уміння визначати думки, які провокують тривогу, та змінювати їх на адаптивні, позитивні думки. Також одним із запропонованих напрямів роботи цих дослідників $\epsilon$ застосування технік роботи в уяві 3 інтрузивними зоровими образами, завдяки яким діти можуть навчитися відновлювати самоконтроль і впоратися 3 відчуттям безпорадності (Dyregrov, 2008; Yule 1994). 
Оскільки психічна травма обмежує людину у звичних способах поведінки, то в неї формуються та виникають певні переконання й принципи, так би мовити, певні концепції (уявлення) про життя. Наприклад, «людям довіряти не можна» або «чужинці - небезпечні», «справедливості немає» i т. ін. Так чи інакше формуються певні концепції, що управляють життям людини. I тепер вона буде помічати лише те, що відповідає цим концепціям (уявленням), а те, що не відповідає, помічати не буде. I тому одне із завдань під час подолання травматичного досвіду полягає в тому, щоб вийти за межі цих концепцій (Погодін, 2013). У цьому випадку умови, що надає робота в групі, найбільш оптимальні, щоб помітити, що деякі люди (учасники) можуть бути не тільки ворожими, або байдужими чи небезпечними, а й відкритими, щирими, такими, що прагнуть до спілкування, намагаються потурбуватись одне про одного; група надає можливість побачити, що є люди, які не обов'язково відторгнуть когось, та, незважаючи на ваш великий страх, бути відторгнутим, вони все ще залишаються поруч. Учасники мають можливість і починають відчувати нові емоції й почуття, наприклад почуття вдячності, довіри, близькості тощо. У цих умовах не так страшно ризикувати. I тут завдання ведучого вчасно побачити це та показати учасникам, дати можливість поставитися до цього, як до нових утворень, акцентувати увагу на усвідомленні учасниками нових спостережень, які в них з'явилися, відносин, котрі виникли один з одним, тобто те нове, що виходить за межі їхнього травматичного досвіду, усе це потрібно інтегрувати в їхне життя. Із часом учасники зможуть відчути більшу сміливість і бажання ризикувати робити щось по-новому. Обов'язково варто підтримати бажання робити щось по-новому або згадати те, що учасники давно робили й навіть забули, як це відбувається 3 ними. Наприклад, радіти життю, дружити 3 кимось, довіряти, любити, спиратися на себе. Це надає можливість відновити певну свободу в поводженні зі світом. Якщо це вдасться та триватиме певний час, учасники зможуть відчути свободу від травматичного досвіду й що він більше не керує ними та їхнім життям.

Якщо говорити про віддалені наслідки психологічного травмування, то основним завданням, на думку О. Л. Венгер, є встановлення нормального соціального й внутрішньосімейного функціонування дітей. Часто вони потребують спеціальної роботи з подолання порушень спілкування з батьками та сиблінгами (братами або сестрами), 
що виникли внаслідок психотравми. Не менш важливою для встановлення нормального стану й функціонування дітей $\epsilon$ спеціальна робота 3 найближчим оточенням дітей, передусім, iз батьками та вчителями (Венгер, 2009).

Висновки. Отже, аналіз теоретичних джерел дає підставу виділити основні чинники, що впливають на ефективність групової психологічної роботи 3 дітьми, які отримали травматичний досвід. Зокрема, вони полягають у тому, що шкільний психолог під час планування групової роботи має враховувати етапи переживання травми, оскільки в одному випадку цілями роботи будуть відреагування травматичних переживань, а в іншому - адаптація дитини до нових (складних) життєвих обставин і, отже, це зумовлює методи й методики роботи. Серед інших чинників важливо враховувати вікові та індивідуальні особливості дітей, їхній емоційний стан, групову динаміку, відносини між учасниками, процеси, що відбуваються всередині групи, уміння керувати ними та вчасно реагувати на будь-які зміни.

Подальших досліджень потребують пошуки та розробка найбільш оптимальної технології й моделі роботи 3 травмованими дітьми в умовах освітнього середовища, а також залучення до цього процесу їхніх батьків.

\section{Література}

1. Bisson, J. I., Ehlers, A., Matthews, R., Pilling, S., Richards, D., \& Turner, S. (2007). Psychological treatments for chronic post-traumatic stress disorder. Systematic review and meta-analysis. British Journal of Psychiatry, (90), 97-104.

2. Dyregrov, A. (2008). Grief in children. A. Handbook for adults (2nd edition). London: Jessica Kingsley Publisers.

3. Frewen, P., \& Lanius, R. (2015). The Norton series on interpersonal neurobiology. Healing the traumatized self: Consciousness, neuroscience, treatment. W. W. Norton \& Company.

4. Friedman, J. M. (1996). PTSD diagnosis and treatment for mental health clinicians. Community Mental Health Journal: journal. April, 173-189.

5. Lee, D. A., James, S. (2013). The Compassionate-Mind Guide to Recovering from Trauma and PTSD: Using Compassion-Focused Therapy to Overcome Flashbacks, Shame, Guilt, and Fear. Oakland, CA: New Harbinger Publications.

6. Khusid, M. (2016). Meditation techniques for posttraumatic stress disorder. In D. M. Benedek \& G. H. Wynn (Eds.), Complementary and alternative medicine for PTSD, 59-86. Oxford University Press.

7. Oaklander, V. (1988). Windows to our children. Highland, NY: The Gestalt Journal Press. 
8. Paone, T. R., Maldonado, J. M. (2008). Child centered play therapy with traumatized children: Review and clinical applications. https://www.researchgate.net/ publication/272819775_Child_centered_play_therapy_with_traumatized_children_Re view_and_clinical_applications

9. Yule, W., Canterbury, R. (1994). The treatment of posttraumatic stress disorder in children and adolescents. International Review of Psychiatry, 6 (2-3), $141-151$.

10. Битянова М. Р (ред.) (2005). Практикум по психологическим играм с детьми и подростками. Санкт-Петербург: Питер.

11. Богданов, С. О., Гірник, А. М., Лазоренко, Б. П., Савінов, В. В., Соловйова, В. В. (2016). Соціально-психологічні чинники порушення стресостійкості дітей, що проживають у буферній зоні воєнного конфлікту на сході України. Проблеми політичної психологї̈, 4 (18), 40-51.

12. Бондарук, Ю. С. (2019). Особливості психологічного консультування при подоланні наслідків психологічного травмування під час супроводу дітей та сімей в освітньому процесі. Virtus: Scientific Journal, (37), 39-43.

13. Венгер, А. Л., Морозова, Е. И. (2009). Психологическая помощь детям и подросткам после Бесланской трагедии. Владимир: Транзит-ИКС.

14. Горбунова, В. В. (2015). Робота з посттравматичним стресовим розладом (ПТСР) у межах когнітивно-поведінкової терапії. Психологічна допомога особистості, що переживає наслідки травматичних подій. Київ: Міленіум, $26-35$.

15. Горностай, П. П. (2013). Динамічні процеси в малій групі: соціальнопсихологічний вимір освітнього середовища: монографія. Кіровоград: ІмексЛТД.

16. Захаров, А. И. (2006). Игра как способ преодоления неврозов у детей. Санкт-Петербург: КАРО.

17. Кори, Д. (2003). Теория и практика группового консультирования. Москва: Эксмо.

18. Лунченко, Н. В., Мельник, А. А., Панок, В. Г., Ткачук, І. І. (2019). Діяльність психологічної служби у системі освіти з надання допомоги дітям і сім'ям, що опинились у складних життєвих обставинах внаслідок військових дій (за результатами моніторингу). Київ: УНМЦ практ. психології і соц. роботи.

19. Лэндрет, Г. Л. (2007). Новые направления в игровой терапии. Москва: Когито-Центр.

20. Мушкевич, М., Федоренко, Р., Мельник, А., Шкарлатюк, К., Грицюк, I., Коширець, В., Дучимінська, Т. (2016). Психологічна допомога учасникам АТО та їх сім'ям: кол. моногр. Луцьк: Вежа-Друк.

21. Панок, В. Г., Ткачук, І. І., Острова, В. Д., Лунченко, Н. В. Бондарук, Ю.С. (2019). Науково-методичні засади надання психосоціальної допомоги дітям, котрі опинились у складних життєвих обставинах внаслідок військових дій. Педагогіка і психологія, 2 (103), 64-71.

22. Погодин, И. А. (2013). Рискуя быть живым. Психотерапия присутствием. Ростов-на-Дону: Феникс. 
23. Романюк, М. (2014). Співпраця психологічної служби і педагогів щодо подолання ПТСР у підлітків. Практичний психолог. Школа, (10), 36-39.

24. Смид, Р. (2000). Групповая работа с детьми и подростками. Москва: Генезис.

25. Тарабрина, Н. В. (2009). Психология посттравматического стресса: теория и практика. Москва: Ин-т психологии РАН.

26. Тарасова, Т. В. (2018) Роль гри та арт-технолопй у подоланні підлітками уразливих категорій посттравматичних стресових розладів. Пост-травматичний стресовий розлад: дорослі, діти та родини в ситуаиії війни, 2, 511-519.

27. Титаренко, Т. М. (2017). Теоретико-методологічні засади соціальнопсихологічної реабілітації особистості в умовах пролонгованої травматизації. Наукові студії із соціальної та політичної психології, 39 (42), 39-50.

28. Титаренко, Т. М. (2018). Психологічне здоров'я особистості: засоби самодопомоги в умовах тривалої травматизації. Кропивницький: Імекс-ЛТД.

29. Удовенко, Ю. М. (2017). Організація соціально-психологічної допомоги дітям, які пережили втрати внаслідок військових дій. Український психологічний журнал, 1 (3), 165-176. DOI: http://doi.org/10.17721/upj.2017.1(3).13

30. Фишер, Г. (2003). Новые пути выхода из травмы. Первая помощь при тяжёлых душевных потрясениях. URL: https://bioraf.ru/gotfrid-fisher-novie-putivihoda-iz-travmi-pervaya-pomoshe-pri.html

\section{References}

1. Bisson, J. I., Ehlers, A., Matthews, R., Pilling, S., Richards D., \& Turner, S. (2007). Psychological treatments for chronic post-traumatic stress disorder. Systematic review and meta-analysis. British Journal of Psychiatry, (90), 97-104.

2. Dyregrov, A. (2008). Grief in children. A. Handbook for adults (2nd edition). London: Jessica Kingsley Publisers.

3. Frewen, P., \& Lanius, R. (2015). The Norton series on interpersonal neurobiology. Healing the traumatized self: Consciousness, neuroscience, treatment. W. W. Norton \& Company.

4. Friedman, J. M. (1996). PTSD diagnosis and treatment for mental health clinicians. Community Mental Health Journal: journal. April, 173-189.

5. Lee, D. A., James, S. (2013). The Compassionate-Mind Guide to Recovering from Trauma and PTSD: Using Compassion-Focused Therapy to Overcome Flashbacks, Shame, Guilt, and Fear. Oakland, CA: New Harbinger Publications.

6. Khusid, M. (2016). Meditation techniques for posttraumatic stress disorder. In D. M. Benedek \& G. H. Wynn (Eds.), Complementary and alternative medicine for PTSD, 59-86. Oxford University Press.

7. Oaklander, V. (1988). Windows to our children. Highland, NY: The Gestalt Journal Press.

8. Paone, T. R., Maldonado, J. M. (2008). Child centered play therapy with traumatized children: Review and clinical applications. https://www.researchgate.net/ 
publication/272819775_Child_centered_play_therapy_with_traumatized_children_Re view_and_clinical_applications

9. Yule, W., Canterbury, R. (1994). The treatment of posttraumatic stress disorder in children and adolescents. International Review of Psychiatry, 6 (2-3), $141-151$.

10. Bytianova, M. R (red.) (2005). Praktykum po psykholohycheskym yhram s detmy y podrostkamy [Workshop on psychological games with children and adolescents]. Sankt-Peterburg: Pyter (in Russian).

11. Bohdanov, S. O., Hirnyk, A. M., Lazorenko, B. P., Savinov, V. V., Solovy̆ova, V. V. (2016). Sotsialno-psykholohichni chynnyky porushennia streso-stiy̆kosti ditey̆, shcho prozhyvaiut u buferniy̆ zoni voiennoho konfliktu na skhodi Ukraïny [Socio-psychological factors of violation of stress-resistance of children living in the buffer zone of the military conflict in eastern Ukraine]. Problemy politychnoi psykholohii - Problems of Political Psychology, 4 (18), 40-51 (in Ukrainian).

12. Bondaruk, Yu. S. (2019). Osoblyvosti psykholohichnoho konsultuvannia pry podolanni naslidkiv psykholohichnoho travmuvannia pid chas suprovodu ditei ta simei $\mathrm{v}$ osvitnomu protsesi [Features of psychological counseling in overcoming the consequences of psychological trauma when accompanying children and families in the educational process]. Virtus: Scientific Journal, (37), 39-43 (in Ukrainian).

13. Venher, A. L., Morozova, E. Y. (2009). Psykholohycheskaia pomoshch detiam y podrostkam posle Beslanskoi trahedyy [Psychological assistance to children and adolescents after the Beslan tragedy]. Vladymyr: Tranzyt-YKS (in Russian).

14. Horbunova, V. V. (2015). Robota z posttravmatychnym stresovym rozladom (PTSR) u mezhakh kohnityvno-povedinkovoi terapii [Work with post-traumatic stress disorder (PTSD) within cognitive-behavioral therapy]. Psykholohichna dopomoha osobystosti, shcho perezhyvaie naslidky travmatychnykh podiy - Psychological assistance to a person experiencing the consequences of traumatic events. Kyiv: Milenium, 26-35 (in Ukrainian).

15. Hornostai, P. P. (2013). Dynamichni protsesy v malii hrupi: sotsialnopsykholohichnyi vymir osvitnoho seredovyshcha [Dynamic processes in a small group: socio-psychological dimension of the educational environment]. Kirovohrad: ImeksLTD (in Ukrainian).

16. Zakharov, A. Y. (2006). Yhra kak sposob preodolenyia nevrozov u detei [Play as a way to overcome neuroses in children]. SPb.: KARO (in Russian).

17. Kory, D. (2003). Teoryia y praktyka hruppovoho konsultyrovanyia [Theory and practice of group counseling]. Moskva: Эksmo (in Russian).

18. Lunchenko, N. V., Melnyk, A. A., Panok, V. H., Tkachuk, I. I. (2019). Diialnist psykholohichnoi sluzhby u systemi osvity z nadannia dopomohy ditiam i simiam, shcho opynylys u skladnykh zhyttievykh obstavynakh vnaslidok viiskovykh dii (za rezultatamy monitorynhu) [Activities of the psychological service in the education system to provide assistance to children and families who find themselves in difficult life circumstances as a result of hostilities (as a result of monitoring)]. Kyiv: UNMTs praktychnoi psykholohii i sotsialnoi roboty (in Ukrainian). 
19. Lendret, H. L. (2007). Novye napravlenyia v yhrovoi terapyy [New directions in play therapy]. Moskva: Kohyto-Tsentr (in Russian).

20. Mushkevych, M., Fedorenko, R., Melnyk, A., Shkarlatiuk, K., Hrytsiuk, I., Koshyrets, V., Duchyminska, T. (2016). Psykholohichna dopomoha uchasnykam ATO ta yikh sim'iam: kolektyvna monohrafiia [Psychological assistance to anti-terrorist operation participants and their families]. Lutsk: Vezha-Druk (in Ukrainian).

21. Panok, V. H., Tkachuk, I. I., Ostrova, V. D., Lunchenko, N. V., Bondaruk, Yu.S. (2019). Naukovo-metodychni zasady nadannia psykhosotsialnoi dopomohy ditiam, kotri opynylys u skladnykh zhyttievykh obstavynakh vnaslidok viiskovykh dii [Scientific and methodological principles of providing psychosocial assistance to children who find themselves in difficult life circumstances as a result of hostilities]. Pedahohika i psykholohiia - Pedagogy and psychology, 2 (103), 64-71 (in Ukrainian).

22. Pohodyn, Y. A. (2013). Ryskuia byt zhyvym. Psykhoterapyia prysutstvyem [At the risk of being alive. Presence psychotherapy]. Rostov-na-Donu: Fenyks (in Russian).

23. Romaniuk, M. (2014). Spivpratsia psykholohichnoi sluzhby i pedahohiv shchodo podolannia PTSR u pidlitkiv [Cooperation of the psychological service and teachers to overcome PTSD in adolescents]. Praktychnyi psykholoh. Shkola-Practical psychologist. School, (10), 36-39 (in Ukrainian).

24. Smyd, R. (2000). Hruppovaia rabota s detmy y podrostkamy [Group work with children and adolescents]. Moskva: Henezys (in Russian).

25. Tarabryna, N. V. (2009). Psykholohyia posttravmatycheskoho stressa: teoryia y praktyka [Psychology of post-traumatic stress: theory and practice]. Moskva: «Ynstytut psykholohyy RAN» (in Russian).

26. Tarasova, T. V. (2018). Rol hry ta art-tekhnolopi u podolanni pidlitkamy urazlyvykh katehorii posttravmatychnykh stresovykh rozladiv [The role of games and art technologies in overcoming vulnerable categories of post-traumatic stress disorders by adolescents]. Post-travmatychnyi stresovyi rozlad: dorosli, dity ta rodyny v sytuatsii viiny - Post-traumatic stress disorder: adults, children and families in a war situation, 2, 511-519 (in Ukrainian).

27. Tytarenko, T. M. (2017). Teoretyko-metodolohichni zasady sotsialnopsykholohichnoi reabilitatsii osobystosti $\mathrm{v}$ umovakh prolonhovanoi travmatyzatsii [Theoretical and methodological principles of socio-psychological rehabilitation of the individual in the conditions of prolonged trauma]. Naukovi studii iz sotsialnoi ta politychnoi psykholohii - Scientific studies in social and political psychology, 39 (42), 39-50 (in Ukrainian).

28. Tytarenko, T. M. (2018). Psykholohichne zdorovia osobystosti: zasoby samodopomohy $\mathrm{v}$ umovakh tryvaloi travmatyzatsii [Psychological health of the individual: means of self-help in the conditions of long-term trauma]. Kropyvnytskyi: Imeks-LTD (in Ukrainian).

29. Udovenko, Yu. M. (2017). Orhanizatsiia sotsialno-psykholohichnoi dopomohy ditiam, yaki perezhyly vtraty vnaslidok viiskovykh dii [Organization of 
social and psychological support to children who have experienced losses due to military actions]. Ukrainskyi psykholohichnyi zhurnal - Ukrainian psychological journal, 1(3), 165-176 (in Ukrainian). DOI: http://doi.org/10.17721/upj.2017.1(3).13

30. Fysher, H. (2003). Novye puty vykhoda yz travmy. Pervaia pomoshch pry tiazhëlykh dushevnykh potriasenyiakh [New ways out of trauma. First aid for severe mental shocks]. URL: https://bioraf.ru/gotfrid-fisher-novie-puti-vihoda-iz-travmipervaya-pomoshe-pri.html_(in Russian).

Received: 05.11.2020

Accepted: 25.11.2020 